политологИя

DOI: 10.17805/trudy.2017.2.8

\title{
ВЫБОРЫ В СТРАНАХ ЕВРОПЫ 2015 г. КАК ФАКТОР ДИНАМИКИ ПОЛИТИЧЕСКОГО РЕЖИМА
}

\author{
E. B. Махора \\ Московский гуманитарный университет
}

\begin{abstract}
Аннотация: В статье показано, что политический процесс в Европе плюралистичен. Выборы, прошедшие осенью 2015 г. в Греции, Португалии, Швейцарии, Польше, Франции и Испании, свидетельствуют о пёстрой политической картине в современной Европе. Выясняются причины роста популярности разных политических сил.

Статья подготовлена на основе доклада автора на ХІІІ Международной научной конференции «Высшее образование для ХХІ века» (8-10 декабря 2016 г., Московский гуманитарный университет).
\end{abstract}

Ключевые слова: Европа; политический режим; выборы; избиратели; парламентские выборы; политические партии

\section{ELECTIONS IN EUROPEAN COUNTRIES IN 2015 AS A FACTOR IN THE DYNAMICS OF THE POLITICAL REGIME}

\author{
E. V. Mahora \\ Moscow University for the Humanities
}

\begin{abstract}
The article shows that the political process in Europe is pluralistic. The elections held in autumn 2015 in Greece, Portugal, Switzerland, Poland, France and Spain are evidence of a parti-colored political picture in Europe. The reasons for the growing popularity of different political forces are elucidated.

The article is based on the author's presentation given at the 13th International Scientific Conference «Higher Education for the 21st Century» (8-10 December 2016, Moscow University for the Humanities).

Keywords: Europe; political regime; elections; voters; parliamentary elections; political parties

Выборы, прошедшие в небольшом временном промежутке друг от друга в ряде стран Европы в 2015 г., могут показать динамику политического режима, как в отдельной стране, так и в Европе в целом.

Директор Институт Европы РАН А. А. Громыко, обобщая итоги избирательных кампаний в странах Европы, отметил их главную отличительную особенность: налицо почти повсеместное отступление партий европей-
\end{abstract}


ского мэйнстрима, появление новых игроков на политическом поле Европы, очевидное усиление партий, ранее считавшихся аутсайдерами (В Институте Европы РАН ..., 2015: Электр. ресурс). Исследователи политических процессов отмечают, что центральной проблемой в теории электорального поведения является объяснение причин голосования или не голосования за те или иные политические партии (Политология, 2012).

В данной статье предпринята попытка выяснить причины роста популярности тех партий в ряде стран Евросоюза, политика которых выступает фактором динамики политических режимов в этих странах. В исследовании данного вопроса, автор опирался на теории электорального процесса.

\section{Внеочередные парламентские выборы в Греции 20152.}

21 августа 2015 г. Премьер-министр Греции Алексис Ципрас подал в отставку и объявил о необходимости провести досрочные парламентские выборы (Ципрас ушел в отставку ..., 2015: Электр. ресурс). Внеочередные парламентские выборы в Греции состоялись 20 сентября 2015 г.

Коалиция радикальных левых сил (СИРИЗА), выступавшая против мер жесткой экономии, победила; партия «Новая демократия» заняла второе место. На фоне проблемы долгов росли и антимигрантские настроения и, как следствие - ультраправая партия «Народное общество Хриси Авги» (или «Золотая Заря») заняла третье место (СИРИЗА победила ..., 2015: Электр. ресурс).

Необходимо отметить тот факт, что 5 июля 2015 г. в Греции состоялся референдум. В Греции многие воспринимали референдум как голосование граждан за или против членства в еврозоне. Около 61\% греков высказались против условий соглашения с кредиторами. Предвыборная программа Коалиции радикальных левых сил совпала с общественным мнением, что в результате привело ее к победе. Однако, большинство населения Греции хочет, чтобы страна осталась в еврозоне и продолжала использовать европейскую валюту (Правительство: референдум в Греции ..., 2015: Электр. ресурс). Вероятно, дальнейшая политика Коалиции левых сил покажет, останется Греция в Евросоюзе или нет.

\section{Парламентские выборы в Португалии 20152.}

На парламентских выборах 4 октября 2015 г. победила правоцентристская коалиция, состоящая из правившей «Социал-демократической партии» во главе с премьер-министром Педру Пасуша Коэлью и «Народной партии». Таким образом, впервые за последние годы правящая коалиция не только осталась у власти до конца своего мандата, но и была переизбрана. Правоцентристская коалиция получила поддержку 36,8\% голосов избирателей, лишившись абсолютного большинства, т. е. оппозиция сможет 
блокировать все ее предложения. Второе место с результатом 32,5 \% заняла Социалистическая партия во главе с Антониу Кошта (Затягивание поясов ... , 2015: Электр. ресурс).

Вполне очевидно, учитывая высокий уровень безработицы и миграции граждан Португалии, что экономическая ситуация в стране была одной из главных тем предвыборной кампании (Португалия готовится ..., 2015: Электр. ресурс). Антониу Кошта в случае победы на выборах обещал покончить с мерами жёсткой экономии. (Затягивание поясов ..., 2015: Электр. ресурс).

В связи с тем, что правоцентристская коалиция лишилась абсолютного большинства, могла возникнуть политическая нестабильность в парламенте. Как следствие этого, спустя 11 дней парламент Португалии отправил правительство в отставку. Инициатором голосования по вотуму недоверия правительству выступил Антониу Кошта («Левый поворот» ..., 2015: Электр. ресурс).

\section{Выборы в федеральный парламент в Швейцарии в 20152.}

Выборы в федеральный парламент состоялись 18 октября 2015 г. (Парламентские выборы в Швейцарии ..., 2015: Электр. ресурс).

Правоконсервативная Швейцарская народная партия (ШНП), выступавшая за жесткое ограничение миграционных потоков и против вступления Швейцарии в Евросоюз, одержала победу на выборах, получив $28 \%$ голосов избирателей. В результате, у данной партии 65 мест в парламенте из 200. Это лучший результат для одной партии на выборах за последние 100 лет (Филипенок, 2015 : Электр. ресурс).

На втором месте оказалась Социал-демократическая партия, выступавшая за более тесное сотрудничество с Евросоюзом и умеренную реформу миграционной политики. За данную партию проголосовало $18 \%$ избирателей (43 места в парламенте). Либерально-демократическая партия заняла третье место, получив 16\% голосов избирателей. (На выборах в Швейцарии ..., 2015: Электр. ресурс).

По оценкам политологов, победа Швейцарской народной партии обусловлена миграционным кризисом в Европе.

Также, политологи прогнозируют смещение сил в новом Национальном совете от левоцентристского крыла к правоцентристскому.

Разрыв между Швейцарской народной партией и Социал-демократической партией составляет 11\%. Данный факт, вероятно, означает, что граждане Швейцарии на момент проведения выборов не приняли единогласного решения по поводу миграционной политики и вступления страны в Евросоюз. 


\section{Парламентские выборы в Польше в 2015 2.}

Парламентские выборы в Польше состоялись в октябре в 2015 г.

На выборах в Сейм победила консервативная партия «Право и справедливость» с результатом 39,1\% голосов. «Право и справедливость» считается партией «евроскептиков» (Партия «евроскептиков» ..., 2015: Электр. ресурс). Второе место с результатом 23,4\% заняла правящая либеральная партия «Гражданская платформа». Ее проигрыш может быть связан с повышением пенсионного возраста в стране и тем обстоятельством, что более двух миллионов трудовых мигрантов перебрались за рубеж.

Движение рок-музыканта Павла Кукиза Kukiz'15 получило 9\% голосов избирателей и заняло третье место.

Впервые с 1989 г. большинство мандатов в Сейме будет находиться в руках одной партии. (Офицеров-Бельский, 2015: Электр. ресурс).

Победа партии «Право и справедливость» в большой степени была предсказуема, т. к. с начала предвыборной кампании данная партия, по данным социологических опросов, значительно опережала правящую партию «Гражданская платформа».

Неожиданно, впервые в истории современной Польши в парламент страны не вошла левица (польское название левых партий). Данный факт, вероятно, говорит в целом о кризисе «левой идеи» в Польше (Ворожеина, 2015: Электр. ресурс).

Победа на выборах партии «Право и справедливость» может привести к расхождению с политическим курсом Евросоюза.

\section{Региональные выборы во Франщии 2015 г.}

Первый тур региональных выборов прошел 6 декабря 2015 г., второй тур - 13 декабря 2015 г.

В Париже 13 ноября 2015 г. произошли теракты. В связи с этим, значительно изменились повестки дня всех политических партий: они особое внимание уделяли вопросам безопасности и проблемам мигрантов. На этом фоне усилилось влияние правой оппозиционной националистической партии «Национальный фронт». В первом туре данная партия одержала победу, получив средне по стране 29,9\% голосов избирателей.

После проведения первого тура голосования главные политические партии Франции приложили усилия, чтобы не допустить победу партии «Национальный фронт» (Избирательная практика ..., 2015: Электр. ресурс). Например, хотя Николя Саркози отказался вступать в союзы с левыми, социалисты - ради торжества «республиканских ценностей» (т. е. победы правых над ультраправыми) - в двух регионах отозвали своих кандидатов, которые прошли во второй тур (Сафронов, 2015: Электр. ресурс).

Предпринятые меры оказались эффективными. В результате, «На- 
циональному фронту» не удалось получить большинство ни в одном из советов. Данное обстоятельство, по мнению экспертов, также может быть связано с высокой явкой: $58 \%$.

Коалиция консерваторов во главе с партией бывшего президента Франции Николя Саркози «Союз за народное движение» выиграла выборы, завоевав большинство в 7 региональных советов из 13 регионов. Таким образом, правящая «Социалистическая партия» будет управлять в 5 регионах (Ильина, 2015: Электр. ресурс).

Ряд экспертов считает, что в первом туре выборов произошло «протестное голосование», т. е. голосование за любую партию, кроме «Социалистической партии», политикой которой многие избиратели были недовольны (Балдина, 2015: Электр. ресурс). Вероятно, прошедшие выборы во Франции не являются однозначными с точки зрения голосования избирателей. В экспертном сообществе результаты региональных выборов во Франции 2015 г. рассматривают как показатель расстановки политических сил в стране перед президентскими выборами в 2017 г. (Избирательная практика ..., 2015: Электр. ресурс). Данные выборы, скорее всего, более определенно покажут политические настроения граждан Франции.

\section{Парламентские выборы в Испании 2015 г.}

Парламентские выборы в Испании прошли 20 декабря 2015 г. Правящая в Испании правая Народная партия победила на выборах в Испании. Народная партия получила от 114 до 118 мест в парламенте, второе место с 81-85 мандатами у Испанской социалистической рабочей партии, третье - y Podemos (76-80 мандатов), четверку лидеров замыкает партия «Граждане» (от 47 до 50 мест) (Exit poll: ..., 2015:Электр.ресурс).

Данные парламентские выборы завершили эпоху двухпартийной системы. Возвращение к двухпартийной системе в обозримом будущем вряд ли возможно. Соответственно, перед партиями стояла новая для них задача: научиться работать в новых обстоятельствах, договариваться между собой и создавать новые форматы коалиций (Политолог: ..., 2016: Электр. ресурс). Как показало время, с данными задача партии не справились. Например, Испанской социалистической рабочей партии во главе с Педро Санчесом удалось договориться только с партией «Граждане». Стоит отметить, Педро Санчес стал первым в истории Испании кандидатом на пост премьера, чью кандидатуру заблокировал парламент.

В результате, конгрессу депутатов не удалось договориться по кандидатуре на пост премьера, и король Испании Фелипе VI подписал указ о роспуске обеих палат парламента и проведении в стране досрочных выборов 26 июня 2016 г. Подобная ситуация произошла в истории демократической Испании впервые (Король Испании ..., 2016: Электр. ресурс). 


\section{Заключение}

Подводя итоги рассмотренных выше выборов, можно сделать следующие выводы:

1) В Греции на внеочередных парламентских выборах победила Коалиция радикальных левых сил (СИРИЗА). На парламентских выборах в Португалии одержала победу правоцентристская коалиция. В Швейцарии победа на выборах в федеральный парламент осталась за правоконсервативной Швейцарской народной партией (ШНП). В Польше на выборах в Сейм победила Консервативная партия «евроскептиков» «Право и справедливость». Во Франции Коалиция консерваторов во главе с партией бывшего президента Николя Саркози «Союз за народное движение» выиграла выборы. На парламентских выборах в Испании большинство избирателей проголосовали за правую Народную партию.

Результаты данных выборов наглядно показывают, что в Европе политический процесс является плюралистическим.

2) Избиратели, за исключением граждан Польши, продолжают одобрять политику правящей партии, несмотря на сложную экономическую ситуацию, острый миграционный вопрос и высокий уровень безработицы в определенных странах. Однако, это не свидетельствует о политической стабильности.

3) Необходимо отметить, что на выборах в Швейцарии победила партия, выступавшая против вхождения страны в Евросоюз, в Польше - партия, выступавшая против политики Евросоюза. В Греции третье место на выборах заняла ультраправая партия. Возможно, граждане этих трех стран не доверяют политике Евросоюза, что может привести к очередному кризису.

4) В Греции и Польше наблюдаются изменения в составе парламента. Победа «Национального фронта» в первом туре на региональных выборах во Франции означает серьезную заявку на будущие выборы для лидера данной партии. Вероятно, что политическая повестка данных стран в будущем несколько изменится.

\section{СПИСОК ЛИТЕРАТУРЫ}

Балдина, А. (2015) Страх или воля к переменам? Региональные выборы во Франции выиграл Нацфронт [Электронный ресурс] // Вести.Ru. 07 декабря. URL: http://www.vesti.ru/doc.html?id=2695146 (дата обращения: 27.09.2016).

В Институте Европы РАН состоялся круглый стол «Избирательный цикл в странах Евросоюза: итоги выборов 2015 г.: перспективы на будущее» (2015) [Электронный ресурс] // Историческая и социально-образовательная мысль. Т. 7, № 8. URL: http://www.hist-edu.ru/hist/article/viewFile/2028/1958 
(дата обращения: 26.09.2016).

Ворожеина, Я. (2015) «Право и справедливость»: польско-российские отношения - вызов для Варшавы, [Электронный ресурс] //Аналитический портал RuBALTIC.Ru. 26 октября. URL: http://www.rubaltic.ru/article/politikai-obshchestvo/261015-pravo-i-spravedlivost/ (дата обращения: 26.09.2016).

Затягивание поясов по-португальски прошло испытание выборами (2015) [Электронный ресурс]//Euronews.05 октября.URL: http://ru.euronews. com/2015/10/05/passos-coelho-wins-re-election-in-portugal-says-ready-tocompromise (дата обращения: 22.09.2016).

Избирательная практика: Региональные выборы во Франции 2015 года (2015) [Электронный ресурс] // Центральная избирательная комиссия Республики Татарстан. 28 декабря.URL: http://izbirkom.tatarstan.ru/rus/index. htm/news/529804.htm (дата обращения: 27.09.2016).

Ильина, Н. (2015) Антииммигрантский «Национальный фронт» не победил ни в одном регионе Франции [Электронный ресурс] // Ведомости. 14 декабря. URL: https://www.vedomosti.ru/politics/articles/2015/12/15/620953le-pen-ne-proshla (дата обращения: 27.09.2016).

Король Испании подписал указ о проведении досрочных выборов 26 июня (2016) [Электронный ресурс] // РИА Новости. 3 мая. URL: https://ria.ru/ world/20160503/1425404555.html (дата обращения: 28.09.2016).

На выборах в Швейцарии в лидеры вышли противники миграции (2015) [Электронный ресурс] // Lenta.ru. 19 октября. URL: https://lenta.ru/ news/2015/10/19/switzerland/ (дата обращения: 23.09.2016).

Офицеров-Бельский, Д. (2015) К итогам парламентских выборов в Польше [Электронный ресурс] // Внешняя политика - аналитическое агентство. 27 октября. URL: http://www.foreignpolicy.ru/analyses/k-itogamparlamentskih-vyborov-v-polshe/ (дата обращения: 26.09.2016).

Парламентские выборы в Швейцарии. Досье (2015) [Электронный ресурс] // Центральное государственное информационное агентство России. 16.10.2015 URL: http://tass.ru/info/2353766 (дата обращения: 26.09.2016).

Партия «евроскептиков» Ярослава Качиньского одержала победу на выборах в Польше (2015) [Электронный ресурс] // RT на русском. 26 октября. URL: https://russian.rt.com/article/125840 (дата обращения: 26.09.2016).

Политология (2012) : учебник для вузов / В. И. Буренко, В. Г. Ледяев, В. В. Меркулов и др.; под ред. В. И. Буренко. М. : КНОРУС. 387 с.

Политолог: Испания может избежать досрочных выборов в последний момент (2016) [Электронный ресурс] // Международная мониторинговая организация CIS-EMO CIS-Europe Monitoring Organization. 29 марта. URL: http:/www.cis-emo.net/ru/news/politolog-ispaniya-mozhet-izbezhatdosrochnyh-vyborov-v-posledniy-moment (дата обращения: 28.09.2016).

Португалия готовится к парламентским выборам (2015) [Электронный 
pecypc] // Euronews. 03 октября. URL: http://ru.euronews.com/2015/10/03/ portugal-set-for-sunday-s-election (дата обращения: 22.09.2016).

«Левый поворот» в Португалии: судьбуправительства решит президент (2015) [Электронный ресурс]// Euronews. 10 ноября. URL: http://ru.euronews. com/2015/11/10/portugal-pm-passos-coelho-defeated-by-anti-austerity-mps (дата обращения: 22.09.2016).

Правительство: референдум в Греции 5 июля не будет иметь отношения к евро или драхме (2015) [Электронный ресурс] // Центральное государственное информационное агентство России. 28 июня. URL: http://tass. ru/mezhdunarodnaya-panorama/2077801 (дата обращения: 21.09.2016).

Сафронов, Ю. (2015) Марин Ле Пен больше Олланда и Саркози [Электронный ресурс] // Новая газета. 07 декабря. URL: https://www.novayagazeta. ru/articles/2015/12/07/66692-marin-le-pen-bolshe-ollanda-i-sarkozi (дата обращения: 27.09.2016).

СИРИЗА победила на выборах, набрав 35,47\% голосов (2015) [Электронный ресурс] // Международная мониторинговая организация CIS-EMO CISEurope Monitoring Organization. 21 сентября. URL: http://www.cis-emo.net/ ru/news/siriza-pobedila-na-vyborah-nabrav-3547-golosov (дата обращения: 21.09.2016).

Филипенок, А. (2015) Противники ЕС и мигрантов выиграли выборы в Швейцарии [Электронный ресурс] // РБК. 18 октября. URL: http://www. rbc.ru/politics/18/10/2015/5623ece29a7947ab86b444e8 (дата обращения: 23.09.2016).

Ципрас ушел в отставку и объявил о досрочных выборах (2015) [Электронный ресурс] // ВBC Русская служба. 20 августа. URL: http://www.bbc. com/russian/international/2015/08/150820_tsipras_resignation_greece (дата обращения: 21.09.2016).

Exit poll: правящая Народная партия победила на выборах в Испании (2015) [Электронный ресурс] // РИА Новости. 20 декабря.URL: https://ria.ru/ world/20151220/1345851775.html (дата обращения: 28.09.2016).

Дата поступления: 31.10.2016 г.

Махора Екатерина Витальевна - аспирант кафедры философии, культурологии и политологии Московского гуманитарного университета. Адрес: 111395, Россия, г. Москва, ул. Юности, д. 5. Тел.: +7 (985) 265-43-97. Эл. адрес: katrinmak17@rambler.ru. Научный руководитель - д-р полит. н., профессор В. И. Буренко. 
Makhora Ekaterina Vitalievna, Postgraduate Student, Department of Philosophy, Culturology and Politology, Moscow University for the Humanities. Postal address: 5, Yunosti St., Moscow. Russian Federation 111395. Tel.: +7 (985) 265-43-97. E-mail: katrinmak17@rambler.ru. Scientific Adviser - V. I. Burenko, Doctor of Politology, Professor.

\section{Для цитирования:}

Махора Е. В. Выборы в странах Европы 2015 г. как фактор динамики политического режима [Электронный ресурс] // Научные труды Московского гуманитарного университета. 2017, № 2. URL: http://journals.mosgu.ru/trudy/article/view/454 (дата обращения: дд.мм.гг.). DOI: 10.17805/trudy.2017.2.8 